\title{
Tetrahydropalmatine reduces cell death and improves functional recovery after traumatic spinal cord injury in rats
}

\author{
Haihu Hao*, Qiang Liu, Dou Wu, Hao Xing, Yahui Geng \\ Department of Orthopedics, Shanxi Academy of Medical Sciences \& Shanxi Da Yi Hospital, Taiyuan 030032, China \\ ${ }^{*}$ For correspondence: Email: HeimsRacquyende@yahoo.com; Tel: 0086-1322214414
}

Sent for review: 16 November 2018

Revised accepted: 20 March 2019

\begin{abstract}
Purpose: To investigate the effectiveness of tetrahydropalmatine (THP) in the treatment of spinal cord injury (SCl) in rats.

Methods: Adult Sprague Dawley rats were divided into 3 groups: normal control group, SCl group, and $\mathrm{SCl}$ group treated with THP (100 mg kg-1). The effect of THP on spinal cord water content, levels of inflammatory mediators, oxidative stress and apoptosis were determined. Locomotor activity in rats was measured using Basso, Beattie and Bresnahan (BBB) scores. Various oxidative stress markers as well as cytokine levels (NF-KB, IL-6, IL-1 $\beta$ and TNF- $\alpha$ were determined. Apoptotic index was measured using TUNEL assay.

Results: After $72 \mathrm{~h}$ of treatment with THP, BBB scores in SCl group of rats significantly increased from $4.19 \pm 0.41$ to $8.89 \pm 0.47(p<0.05)$. Tunel assay revealed a higher apoptotic index $(42.50 \pm 3.19)$ in the tissues of $\mathrm{SCl}$ rats than in $\mathrm{SCl}$ rats treated with $\mathrm{THP}(31.48 \pm 1.19, p<0.01)$. Expressions of inflammatory cytokines were significantly upregulated in SCl rats. However, THP administration resulted in significant downregulation of the expressions $(p<0.01)$.

Conclusion: These results indicate that THP attenuates traumatic SCl in rats via modulation of the levels of anti-inflammatory mediators. Thus, THP has a promising potential for the management of SCl.
\end{abstract}

Keywords: Tetrahydropalmatine, Spinal cord injury, Cytokines, Edema, Neuroprotection

\begin{abstract}
This is an Open Access article that uses a fund-ing model which does not charge readers or their institutions for access and distributed under the terms of the Creative Commons Attribution License (http://creativecommons.org/licenses/by/4.0) and the Budapest Open Access Initiative (http://www.budapestopenaccessinitiative.org/read), which permit unrestricted use, distribution, and reproduction in any medium, provided the original work is properly credited.

Tropical Journal of Pharmaceutical Research is indexed by Science Citation Index (SciSearch), Scopus, International Pharmaceutical Abstract, Chemical Abstracts, Embase, Index Copernicus, EBSCO, African Index Medicus, JournalSeek, Journal Citation Reports/Science Edition, Directory of Open Access Journals (DOAJ), African Journal Online, Bioline International, Open-J-Gate and Pharmacy Abstracts
\end{abstract}

\section{INTRODUCTION}

One of the most devastating forms of injury which causes psychological and physical impact on an individual is spinal cord injury ( $\mathrm{SCl})$. Traumatic $\mathrm{SCl}$ remains a life-threatening condition with high mortality worldwide. Spinal cord injury $(\mathrm{SCl})$ has unfamiliar pathogenesis which makes it a clinical challenge [1]. A wide spectrum of mechanistic and therapeutic possibilities for $\mathrm{SCl}$ treatment has been speculated. However, there is still need for an effective remedy for $\mathrm{SCl}$-induced tissue damage. Spinal cord injury initiates a series of primary and secondary responses which need to be taken care of [2]. Traumatic spinal damage triggers on a cascade of immune responses which lead to death of oligodendrocytes and neurons and scar 
development, and may even degenerate to irreversible neurological dysfunction. It is known that $\mathrm{SCl}$ induces severe damage to localized nerve endings, leading to necrosis and formation of cavities which degenerate to scar development. Thus, SCI leads to degeneration of normal brain and cardiovascular functions [3].

Spinal cord injury may be due to severe accidents or strong mechanical impacts. The impact created locally produces oedema, electrolyte imbalance, fluctuations in energy metabolism, impaired biochemical functions, reduction in blood flow, changes in vascular permeability, and tissue disruption which may affect microglia and endothelial cells [4]. Ultimately, $\mathrm{SCl}$ affects and disturbs the quality of life of the affected patients, due to inability to maintain normal posture, uncontrollable bowel and bladder functions, insomnia and loss of libido [5].

Neural damage during $\mathrm{SCl}$ is due to elevated levels of inflammatory mediators such as TNF-a IL-1B, IL-6 and NF-kB [6]. Oxidative stress due to presence of free radicals and inflammation progressively lead to apoptosis of neuronal cells, and hence have contributed considerably to current understanding of the pathology of $\mathrm{SCl}$ [7]. Mechanical damage to the spinal cord can initiate secondary responses such as changes in the vascular characteristics and ionic concentration and levels of neurotransmitters [8]. Moreover, inflammation may be precipitated by excessive production of reactive oxygen species (ROS), peroxides and free radicals [9]. Neurological vascular injuries may be aggravated by ROS, oedema, and proteases such as caspase, metalloproteinases and phospholipases [10]. The experimental model of $\mathrm{SCl}$ in animals is produced by compression of the spinal cord. This reduces locomotor activity and produces hyperactivity of neurogenic detrusor. The injury could be visualized through microscopic observations [11].

Tetrahydropalmatine (THP) is an alkaloid present in Rhizoma corydalis. Its antioxidant, neuroprotective, cardio-protective, anti-apoptotic, sedative and analgesic effects have been established [12]. Recently, it was reported that THP exerted protective effects against Japanese encephalitis by modulating the expressions of pro-inflammatory cytokines [13]. The present investigation was carried out to study the influence of THP on the expressions of various mediators involved in SCl. The investigation was carried out to unravel the attenuating effect of THP on signs and symptoms of $\mathrm{SCl}$, and the possible mechanisms involved, with respect to the anti-inflammatory signal pathway, recovery of locomotor activity, reduction in spinal oedema and induction of apoptosis.

\section{EXPERIMENTAL}

\section{Animals and experimental protocol}

All animal care and experimentation were performed in accordance with the American Physiological Society's guiding principles for the care and use of animals [14], and approved by Committee for Ethics in Animal Studies, Shanxi Academy of Medical Sciences, Taiyuan, China (approval no. SAMS/CEAS/139). Adult Male Sprague-Dawley rat, weighing in a range of 270 to $310 \mathrm{~g}$, were procured from the Central Animal Laboratory, Shanxi Academy of Medical Sciences, Taiyuan, China.

Thirty-six animals were randomly divided into three groups. Group I included animals that were exposed to mere surgical process and were not induced with SCl, Group II animals were induced with $\mathrm{SCl}$ and left untreated, and Group III rats were induced with $\mathrm{SCl}$ and treated with THP (100 $\mathrm{mg} / \mathrm{kg}$ in PBS intraperitoneally). The animals were housed in non-pathogenic and temperature-controlled environment in separate cages and exposed to $12 \mathrm{~h}$ cycle of dark and light, with free access to food and water consumption.

Anaesthesia was induced by injecting sodium pentobarbital (50 $\mathrm{mg} / \mathrm{kg}$ intraperitoneally), followed by an incision of $2 \mathrm{~cm}$ made laterally to vertebrae (T7 to T10) and the thoracolumbar fascia and muscular part of spinal region was slit laterally and pulled-in. Under microscopic observation, the muscles from T8-T9 bony segment of backbone were operated and subjected to extradural compression using a vascular clip for $30 \mathrm{sec}$ (30 g forces, Kent Scientific Corp., USA) for induction of spinal cord injury. The spinal cord was flushed with physiological buffer saline solution and, the muscles and skin were stitched back with biodegradable sutures and this site was marked using non-biodegradable suture [15]. After completion of the surgical procedure, the rats were brought back to their respective cages, and were monitored for their vital signs. Ischemia in the spinal cord coupled with swelling, tail control response, reflex in the lower body movement and legs, and appearance of mild paralysis were visualized as markers of $\mathrm{SCl}$. The animals received ampicillin injection to the peripheral back muscles once every three days, to reduce the chances of infection due to surgery, if any. 
Group I ( $n=12)$ was sham group and the animals were exposed to surgical procedure but were not induced with $\mathrm{SCl}$ and were injected with PBS solution 15 min after surgery, and thrice per day for three days. Group II $(n=12)$ rats were surgically operated and induced with $\mathrm{SCl}$ and received PBS solution intraperitoneally three times daily for three days. Rats from Group III ( $n$ $=12$ ) were induced with $\mathrm{SCl}$ after surgical procedure and injected with THP $(100 \mathrm{mg} / \mathrm{kg}$ intraperitoneally) solution prepared in physiological saline. The animals were subjected for the study of locomotor activity, and then euthanized by cervical dislocation method. For conduction of electrophoretic mobility shift assay (EMSA), enzyme linked immunosorbent assay (ELISA) and determination of wet:dry spinal cord weight index, six animals were exsanguinated using cardia puncture technique. The spinal cords across the site of injury were immediately cut, and subjected to determination of wet: dry index, and the remainder mass was subjected to cryopreservation in liquid nitrogen. For performing terminal deoxynucleotidyl transferase-mediated dUTP nick end labelling (TUNEL), six rats from each group were perfused with cold $\left(4^{\circ} \mathrm{C}\right)$ saline solution into the left ventricle and then exposed to neutral buffered formalin (4\%). The spinal cords were stored for the next $14 \mathrm{~h}$ in neutral buffered formalin (4\%), and then grafted in paraffin for histopathological examination [16].

\section{Assessment of revival of neuronal functionality}

The recovery of locomotor activity was studied in an open field using method as reported earlier [17]. The Basso, Beattie and Bresnahan (BBB) method was adopted to rank neuronal-locomotor co-ordination. The scale of 0 to 21 was used, where 0 indicates complete paralysis and 21 indicates normal locomotion. BBB scores categorize various possible locomotor combinations which are used as markers for $\mathrm{SCl}$ measurement such as, movement of hindlimb, joint movement, supporting body weight, trunk posture and stability, walking steps, placement of paws, clearance of toes while walking and tail position. The activity of animal hindlimb was analysed after every $24 \mathrm{~h}$ post-surgery, for $72 \mathrm{~h}$. The BBB scores from 0 to 7 indicate hind limb joints activity, 8 - 14 indicate co-ordination of hindlimbs, and 15-21 revealed improvement of paw activities during locomotion. The observations were carried out by two individuals with sound technical knowledge about the study but were completely unknown about the animal groups. The values obtained were recorded as mean \pm SD.

\section{Wet: dry spinal cord weight index}

Water content in the spinal cord was determined according to the method reported earlier [18]. The weight of the spinal cord was recorded as soon as it was removed (WW), and the respective spinal cords were subjected to drying at $110{ }^{\circ} \mathrm{C}$ for $24 \mathrm{~h}$ in a hot air oven and weighed again to record dry weight (DW).

\section{Western blot}

A mixture of $20 \mathrm{mM}$ Tris hydrochloride $(\mathrm{pH} 7.6)$, sodium dodecyl sulfate $(0.2 \%)$, aprotinin $(0.11$ $\mathrm{IU} / \mathrm{mL}$ ) Triton X-100 (1 \%), deoxycholate (1 \%) and phenyl methyl sulfonyl fluoride $(1 \mathrm{mM})$ (Sigma-Aldrich Inc., St. Louis, USA) was used for breakdown of cryopreserved spinal cord segment. The resulting homogenate was subjected to cooling centrifuge at $14000 \times \mathrm{g}$ for $15 \mathrm{~min}$. The lysate collected was subjected to protein estimation using Bradford method by assay kit (Kangcheng Biotech., China). The samples were subjected to electrophoretic separation using SDS-PAGE on a polyvinylidene difluoride membrane (Bio-Rad Laboratories, CA, USA). The membrane was pre-blocked with in skimmed milk (5\%) for $2 \mathrm{~h}$ at $22^{\circ} \mathrm{C}$ and was then incubated for $12 \mathrm{~h}$ at $4^{\circ} \mathrm{C}$ with primary antibodies targeted against TLR4 protein (Santa Cruz Biotech., CA, USA) in physiological buffer saline solution containing Tween 20 (1:3000), and the control employed was solution of glyceraldehyde 3-phosphate dehydrogenase (GAPDH) in physiological buffer saline solution containing tween (1:10000). The membrane was washed for 3-4 times and exposed for one hour to corresponding diluted horseradish peroxidase antibody solution (1:5000). The resulting protein bands were developed using reagents available commercially (Amersham, IL, USA). The specific protein detected were exposed to X-ray films, which were further scanned using Epson perfection scanner (Model 2480+) (Seiko Corporation, Japan). GlykoBandscan software was used for detection of density and the expression of TLR4 protein was quantified by normalizing to GAPDH.

\section{Determination of NF-kB expression}

The protein extraction and quantification were done as reported earlier. EMSA was performed using commercially available kit (Gel Shift Assay System, Thermo Fischer Scientific, USA) and subsequently subjected to laboratory methods. A consensus oligonucleotide base for NF-kB (5'AGT TGA GGG GAC TTT CCC AGG-3') was tagged with $\mathrm{ATP}-\left[\mathrm{\gamma}^{32} \mathrm{P}\right]$ and $\mathrm{T} 4$ polynucleotide kinase. EMSA study was conducted according to 
the procedure reported elsewhere [19]. Computer aided densitometric analysis was conducted to quantify the NF-kB expression.

\section{Evaluation of biochemical parameters of oxidative stress}

Spinal tissues collected from individual study groups were subjected to homogenization (100 $\mathrm{g} / \mathrm{L})$ in physiological buffer saline, and cryocentrifuged at $-10^{\circ} \mathrm{C}$ for $15 \mathrm{~min}$ at $4000 \mathrm{rpm}$ followed by preservation at $-15{ }^{\circ} \mathrm{C}$. Commercially available kits for the estimation of superoxide dismutase (SOD), end-product of lipid peroxidation, malondialdehyde (MD), catalyse (CAT) and glutathione peroxidase (GSH) were procured (Jiancheng Institute of Biology, Nanjing, China) and procedures for quantification were performed as indicated in the respective user manuals.

\section{Determination of inflammatory cytokines}

ELISA kits were procured from commercial suppliers and were used for the detection of spinal cord levels of TNF- $\alpha, I L-1 \beta$ and IL- 6 , following the procedure indicated in the instruction manual provided with the kit (Diaclone Research, France and Biosource, Belgium). The levels of these inflammatory mediators was indicated as $\mathrm{pg} / \mathrm{mg}$ protein.

\section{TUNEL study}

The spinal cord tissues fixed in paraffin blocks were sliced using a microtome, resulting sections of $4 \mu \mathrm{m}$ thickness. Detection of cell deaths, in situ, was done as per the manufacturer's instructions provided along with the POD kit (ISCDD, Boehringer Mannheim, Germany). Sections were stained and visualized using a microscope by pathologists which were blind the study specimens. TUNEL positive cells were visualized as dark brown in colour owing to staining of nuclear membrane and nucleus, were counted [20]. The apoptotic index was calculated as the percentage of TUNEL positive cells in a section of 5 randomly selected areas of the specimens, that were visualized at a magnification of $400 x$ using Olympus optic microscope (CH30, Japan).

\section{Statistical analysis}

The data collected were subjected to statistical treatment using SPSS 15.0 (SPSS Inc, Chicago, USA), and are expressed as mean \pm standard deviation (SD). Sample groups were compared using independent t-test and one-way ANOVA. Statistical significance was set at $p<0.05$.

\section{RESULTS}

\section{Revival of neural functionality}

In the present investigation, the animal model used was Sprague Dawley rat induced with $\mathrm{SCl}$. The rats revealed persistent changes in the neurological functionality. Evaluation of the neural functionality showed mitigation of symptoms of $\mathrm{SCl}$ in the animals that received THP. As shown in Table 1, the BBB score baseline, that is, immediately after surgery was 0 , which reflected successful development of the $\mathrm{SCl}$ model in the experimental rats. Group I (sham-operated group) had normal values of BBB scores at $24 \mathrm{~h}(20.72 \pm 0.86), 48 \mathrm{~h}(19.84 \pm$ $0.32)$ and $72 \mathrm{~h}(20.12 \pm 0.71)$.

In group II animals (SCI without THP treatment), there was statistically significant reduction in BBB score (almost 10-fold; $p<0.01$ ). Group II rats had BBB scores of $2.92 \pm 0.0 .34$ after $24 \mathrm{~h}$, $3.49 \pm 0.28$ after $48 \mathrm{~h}$, and $4.19 \pm 0.41$ after $72 \mathrm{~h}$. In group III SCl rats treated with THP (100 $\mathrm{mg} / \mathrm{kg}$ ), there were statistically significant increases in BBB scores at the three time points: $8.16 \pm 0.45,8.48 \pm 0.39$ and $8.89 \pm 0.47$ after 24 , 48 and $72 \mathrm{~h}$, respectively $(p<0.01)$. Thus, there was improvement in the neural and locomotor functionality due to improved BBB scores after administration of THP, which indicate that THP plays a role in functional recovery from traumatic $\mathrm{SCl}$ in the rat model.

\section{Spinal cord water content}

The spinal cord water content of the experimental animals was determined by calculating the wet: dry spinal cord weight index. The water content of the spinal cord of group I rats was significantly lower $(p<0.01)$ than that of group II animals (SCl rats).

Table 1: BBB scores in the rats after 24,48 and $72 \mathrm{~h}$

\begin{tabular}{lccc}
\hline Group & $\mathbf{2 4} \mathbf{~}$ & $\mathbf{4 8} \mathbf{~}$ & $\mathbf{7 2} \mathbf{~}$ \\
\hline Normal control & $20.78 \pm 0.86$ & $19.84 \pm 0.32$ & $20.12 \pm 0.71$ \\
SCl & $2.92 \pm 0.34^{* *}$ & $3.49 \pm 0.28^{* *}$ & $4.19 \pm 0.41^{* *}$ \\
SCl + THP & $8.16 \pm 0.45^{*}$ & $8.48 \pm 0.39^{*}$ & $8.89 \pm 0.47^{*}$ \\
\hline \multicolumn{4}{c}{$P<0.01$, compared to group I; $p<0.05$, compared to group II $(\mathrm{n}=12)$}
\end{tabular}


In group III rats (SCI + THP), the spinal cord water content was significantly lower than that of group II $(p<0.01)$. These results are shown in Figure 1.

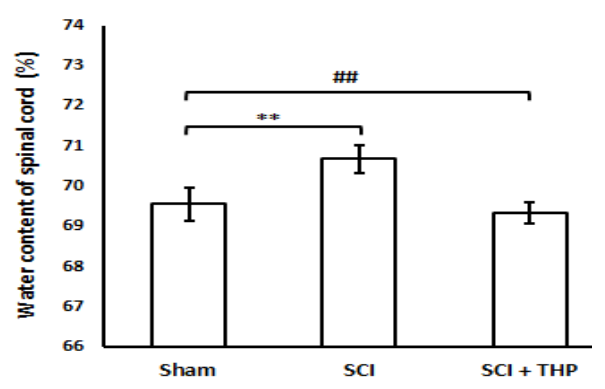

Figure 1: Water content in the spinal cord of group I (sham or normal control group), group II (SCI) and group III (SCl + THP) rats, based on wet: dry index (n $=12$ ). THP treatment in group II rats significantly reduced $\mathrm{SCl}$-induced oedema in spinal cord; ${ }^{* *} p<$ 0.01 , compared to sham (normal control) group; \#\# $p<$ 0.01 compared to $\mathrm{SCl}$ group

\section{Expression of TLR4 in the spinal cord}

Western blot technique was used for estimation of TLR4 expression. Group I (sham group) rats had the lowest TLR4 protein expression, whereas group II rats ( $\mathrm{SCl}$ without $\mathrm{THP}$ ) had significant upregulation of TLR4 protein expression after $72 \mathrm{~h}$. However, administration of THP in group III rats produced significant downregulation of the TLR4 expression after 72 $\mathrm{h}$, relative to group $\mathrm{II}(\mathrm{SCI})$ rats (Figure 3 ).
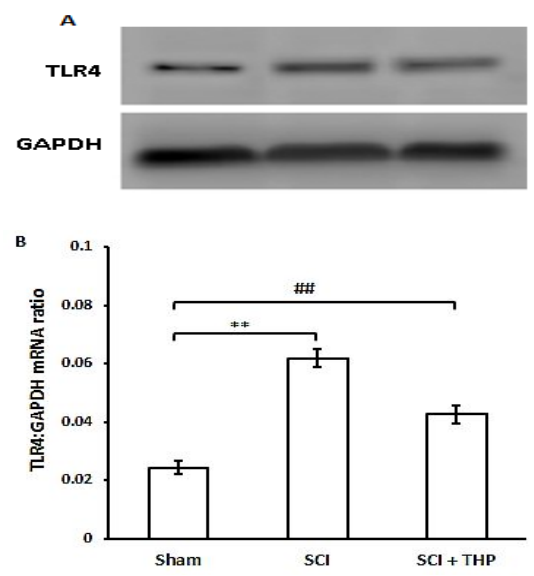

Figure 3: TLR4 expression in the spinal cord, based on TLR4: GAPDH mRNA ratio in group I (sham), group II (SCl) and group III (SCl+THP). 3A: Western blot images indicating reduced expression of TLR4 activity in spinal cord of group I (sham), when compared to that of group II (SCI). In spinal cord of group III ( $\mathrm{SCl}+\mathrm{THP})$ animals, there was a significant reduction in TLR4 expression, as indicated in Figure 3B. THP administration in $\mathrm{SCl}$ rats significantly lowered the TLR4 expression, relative to untreated $\mathrm{SCl}$ rats. ${ }^{* *} p<0.01$, compared to sham group; \#\#p< 0.01 compared to the $\mathrm{SCl}$ group

\section{NF-kB expression}

For determination of NF-KB expression, EMSA technique was used. The binding capacity of the NF-KB DNA in group I rats (sham) was the least amongst the rat groups. Rats in group II (SCl without THP) produced maximum NF-KB DNAbinding capacity after $72 \mathrm{~h}$. There was significant reduction in NF-kB DNA binding capacity in group III rats $(\mathrm{SCl}+\mathrm{THP})$, when compared with group I rats animals ( $<<0.01$; Figure 4$)$. These results confirm the downregulation of NF-kB expression after administration of THP in $\mathrm{SCl}$ rats.

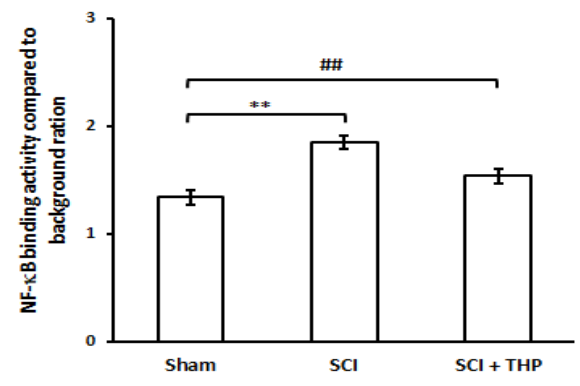

Figure 4: NF-kB DNA binding activity in spinal cord of group I (normal control or sham group), group II (SCI) and group III (SCI + THP). EMSA autoradiography of NF-KB DNA binding in sham group was low, but after $\mathrm{SCl}$ induction, the NF-KB increased. However, treatment of the $\mathrm{SCl}$ rats with THP significantly reduced the NF-KB binding activity; ${ }^{* *} p_{<*}<.01$, compared to normal control (sham) group; ${ }^{\# \#} p<0.01$ compared to the $\mathrm{SCl}$ group $(n=12)$

\section{Oxidative stress mediators}

The levels of SOD and CAT, and GSH were significantly reduced in group II rats ( $\mathrm{SCl}$ group), when compared to group I rats (sham). However, SOD and CAT levels, and GSH expression were significantly elevated in the THP-treated $\mathrm{SCl}$ rats (group III), when compared to the $\mathrm{SCl}$ group (group II). Malondialdehyde (MDA) level was elevated in group II (SCl) rats, whereas it was significantly decreased by THP treatment group III rats $(\mathrm{SCl}+\mathrm{THP})$, relative to group II rats $(\mathrm{SCl})$. These results are presented in Figure 5.

\section{Anti-inflammatory effects of THP}

The levels of TNF- $\alpha, I L-1 \beta$ and IL- 6 in the spinal cord tissue were determined using ELISA kits. Results revealed that induction of $\mathrm{SCl}$ in rats significantly increased the levels of TNF- $\alpha$, IL-1 $\beta$ and IL-6 in the spinal cord of the rats. However, in $\mathrm{SCl}$ rats treated with THP, the levels of TNF-a, IL-1 $\beta$ and IL-6 were significantly reduced, when compared to the untreated group of $\mathrm{SCl}$ rats (group II) (Figure 6). 

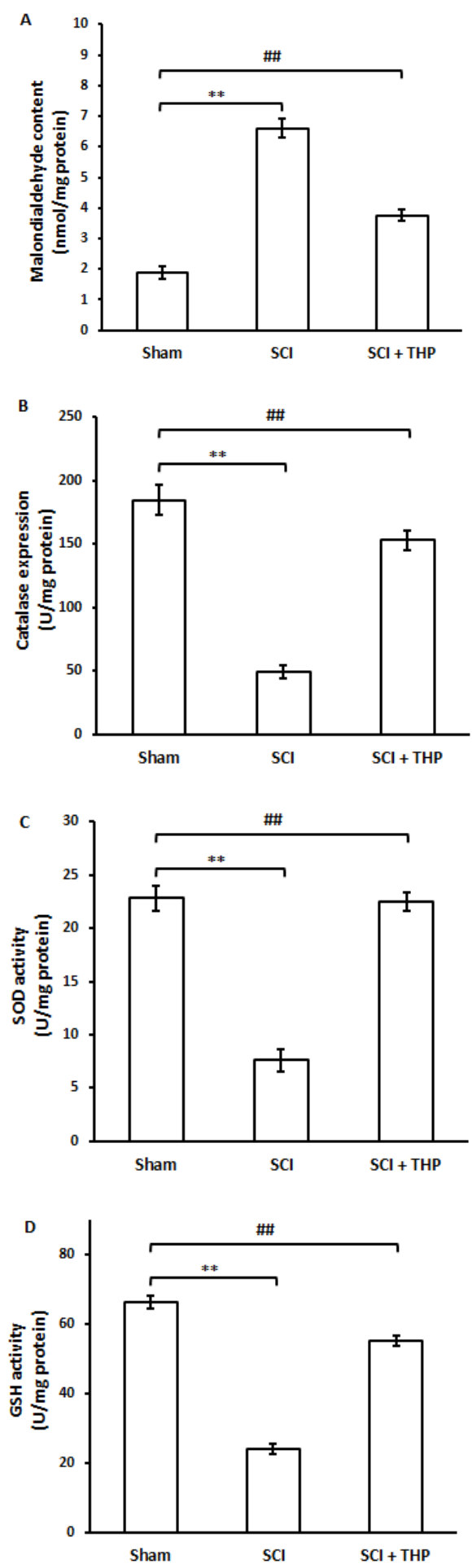

Figure 5: Effect of THP on the spinal cord MDA content of $\mathrm{SCl}$ rats. A: MDA content was significantly increased in $\mathrm{SCl}$ group, relative to normal control (sham) group, whereas THP treatment significantly reduced the MDA levels. B: Catalase expression was higher in normal control (sham) group, whereas it was reduced in $\mathrm{SCl}$ group. Treatment of $\mathrm{SCl}$ rats with THP significantly enhanced catalase activity. C: SOD activity in normal control (sham) group was higher than that in $\mathrm{SCl}$ group, whereas it got normalised after THP administration. D: GSH level in the SCl group was significantly reduced, when compared to normal control (sham) group, but it was subsequently increased by THP administration in group III rats; ${ }^{* *} p<$ 0.01 , compared to normal control (sham) group; \#\# < 0.01 compared to the $\mathrm{SCl}$ group; $\mathrm{n}=12$

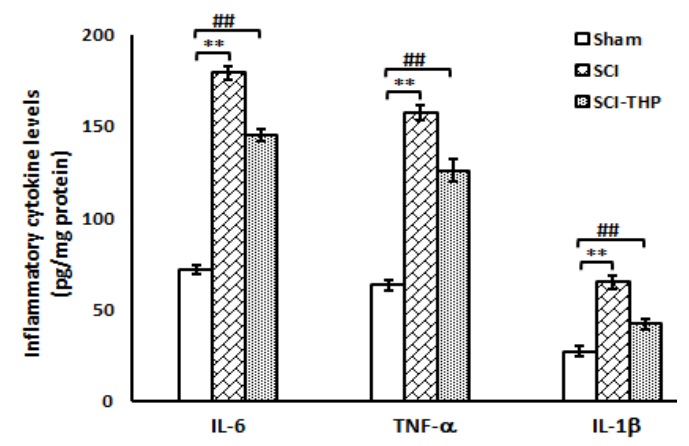

Figure 6: Effect of THP on the levels of inflammatory cytokines in the spinal cord of $\mathrm{SCl}$ rats. There were significant elevations in the levels of IL-6, TNF- $\alpha$ and IL-1 $\beta$ in the injured spinal cord of group II, when compared to normal control (sham) group. In contrast, administration of THP significantly attenuated the cytokine levels in group III rats. ${ }^{* *} p<0.01$, compared to normal control (sham) group; \#\# $<0.01$ versus SCl group

\section{Anti-apoptotic effect of THP}

Spinal cord slides of rats in group I (sham), on microscopic examination, clearly showed absence of apoptotic cells. The cells had intact nuclear and mitochondrial membranes, well distributed chromatin granules and normal endoplasmic reticulum. In contrast, extensive cellular abnormalities such as shrinkage in neuronal size, broken and irregular borders of mitochondria, and swelling of endoplasmic reticulum were seen in the microscopic specimens of group II (untreated SCl) rats. Ultrastructure visualization of specimen from rats representing group III $(\mathrm{SCl}+\mathrm{THP})$ indicated comparatively clearer image with nearly intact nuclear membranes, and uniform appearance of chromatin, coupled with integrity of mitochondria and endoplasmic reticulum. These results are shown in Figures 7 A, B and C.

TUNEL staining provides an insight into DNA damage in cells. The appearance of brown spots indicates TUNEL-positive cells. Group I (normal control) rats had bluish appearance and no brown coloration, indicating absence of TUNELpositive cells. In contrast, there was a large number of brown spots in rat specimens from group II ( $\mathrm{SCl}$ rats), signifying high apoptotic effect due to $\mathrm{SCl}$. However, THP treatment led to a significant reduction in the number of TUNELpositive cells (Figure $7 \mathrm{D}$ ). These results indicate the neuroprotective role of THP in SCl rat model. 


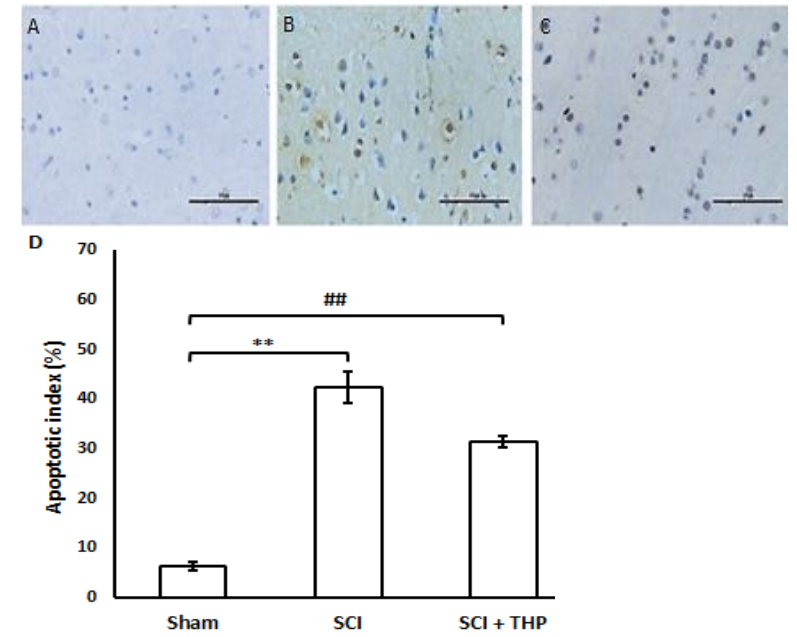

Figure 7: TUNEL immunohistochemistry microphotographs of spinal cord tissue of animals from (A) sham, (B) SCl and (C) $\mathrm{SCl}+$ THP group. A: normal control (sham) group rats showing minimal TUNELpositive cells. $\mathrm{B}$ : $\mathrm{SCl}$ rat spinal cord showing a large population of TUNEL-positive cells. $\mathrm{C}$ : $\mathrm{SCl}+\mathrm{THP}$ rat spinal cord showing significantly less TUNEL-positive cells than SCI. D: THP treatment markedly reduced the apoptotic index in the spinal cord of SCl rats; ${ }^{* *} p<$ 0.01 , compared to normal control (sham) group, \#\#p< 0.01 compared to $\mathrm{SCl}$ group $(n=12)$

\section{DISCUSSION}

Damage due to $\mathrm{SCl}$ produces effects such as oedema, disturbed microcirculation, localized ischemia, lipid peroxidation and eventually apoptosis. These complications limit the effectiveness of currently available $\mathrm{SCl}$ therapies. Damage to the spinal cord is irreversible. However, several deleterious processes occurring at the cellular and molecular levels can be reversed or modified. For example, treatment strategies may correct $\mathrm{SCl}$-associated neuropathological damage, thereby resulting in recovery of the structural and functional integrity of neurons. Traditionally, Corydalis tubers have been used in Korean medicine for the treatment of disorders such as rheumatism, memory dysfunction, cardiac arrhythmia, and ulcers of gastrointestinal tract. The prominent alkaloids in these plants comprise corydaline, corptisine, protopine, tetrahydropalmatine and berberine. Tetrahydropalmatine (THP) has been associated with several therapeutic interventions. Studies have revealed that it exerts cardio-protective, anti-apoptotic, antioxidant, anti-inflammatory, analgesic, neuroprotective and sedative effects [21]. The inflammatory condition produced by Japanese encephalitis virus infection has also been treated successfully with THP.

In the present investigation, traumatic $\mathrm{SCl}$ was induced in experimental rats as reported earlier.
The BBB scores were significantly reduced in $\mathrm{SCl}$ rats, relative to sham-treated rats. Oedema was assessed by measuring the wet weight and dry weight of the spinal cord. The wet weight of the spinal cord was significantly reduced in rats that received THP treatment $(100 \mathrm{mg} / \mathrm{kg})$. This indicates that THP reduces the oedema formed due to induction of $\mathrm{SCl}$ in the rat.

One of the natural protective mechanisms is oxidative stress actively involved in cell-to-cell signalling, cell production and cell death. Due to $\mathrm{SCl}$, there is accumulation of $\mathrm{Ca}^{2+}$ in the cells, which is known to induce loss of mitochondrial functionality, leading subsequently to death of nerve cells. Neuronal damage is attributed to entry of $\mathrm{Ca}^{2+}$ into the mitochondria, a process which subsequently inhibits ATP synthesis. In the present study, THP significantly decreased MDA concentration, enhanced the activities of SOD and CAT, and augmented GSH levels in SCl rats, when compared to untreated $\mathrm{SCl}$ rats. These results indicate the anti-oxidative effect of THP in the treatment of $\mathrm{SCl}$ in the rat. During $\mathrm{SCl}$, several pathophysiological changes occur, including primary mechanical tissue damage, and these may progress to more critical secondary damage in the patient.

The secondary damage is more complex and results in severe inflammation. Within the cells, toll-like receptors modulate the signalling pathways that activate NF-kB and Jun-terminal kinases (JNK) [22]. Under the acute condition of $\mathrm{SCl}$, neural and vascular endothelial cells may release NF-KB, which in turn triggers a cascade of immune activation and expression of several other inflammatory mediators. Reduction in the expression of NF-KB at the early stages may lower the intensity of subsequent inflammatory effects during $\mathrm{SCl}$. One of the inflammatory mediators, TNF- $\alpha$ has various in vivo biological responses, including immunomodulation and inflammatory responses [23]. After traumatic $\mathrm{SCl}$ episode, macrophages, neurons, endothelial and glial cells are known to produce NF-KB which further modulate transcriptional RNA for upregulation of NF-KB and TNF- $\alpha$. In the present study, the higher levels of TNF- $\alpha$ seen in the SCl group is an indication of increased activation of NF-KB. Apart from TNF- $\alpha$, elevated levels of IL$1 \beta$ and IL- 6 are indicative of SCl event $[25,26]$. In the investigation reported herewith, there was significant elevation in the levels of inflammatory mediators in the rats traumatized with $\mathrm{SCl}$. Moreover, there were significant reductions in the expressions of TNF- $\alpha$, IL- $1 \beta$ and IL- 6 in SCI rats treated with THP, when compared to the untreated $\mathrm{SCl}$ rats. Results from TUNEL assay indicated strong neuroprotective effect of THP in 
$\mathrm{SCl}$ rats. The $\mathrm{SCl}$ trauma caused a significant increase in the number of TUNEL-positive cells, as indicated by brown coloration in the visualized specimens. In contrast, marked reduction in the number of TUNEL-positive cells was observed in specimens from $\mathrm{SCl}$ rats treated with THP.

\section{CONCLUSION}

Tetrahydropalmatine induces therapeutic effects in a rat model of SCl. It exerts neuroprotective, anti-inflammatory and anti-oxidant effects in the spinal cord tissues of $\mathrm{SCl}$ rats. Thus, THP has promising potentials for the treatment of $\mathrm{SCl}$. However, further investigations at the clinical level are required on the neuroprotective effects of THP against SCI.

\section{DECLARATIONS}

\section{Acknowledgement}

The authors acknowledge the administration of Shanxi Academy of Medical Sciences and Shanxi Da Yi Hospital, Taiyuan, China for providing facilities and funds required for the research.

\section{Conflict of Interest}

No conflict of interest associated with this work.

\section{Contribution of Authors}

The authors declare that this work was done by the authors named in this article and all liabilities pertaining to claims relating to the content of this article will be borne by them.

\section{Open Access}

This is an Open Access article that uses a funding model which does not charge readers or their institutions for access and distributed under the terms of the Creative Commons Attribution License (http://creativecommons.org/licenses/by/ 4.0) and the Budapest Open Access Initiative (http://www.budapestopenaccessinitiative.org/rea d), which permit unrestricted use, distribution, and reproduction in any medium, provided the original work is properly credited.

\section{REFERENCES}

1. Cadotte DW, Fehlings MG. Spinal cord injury: a systematic review of current treatment options. Clin Orthop Relat Res 2011; 469(3): 732-741.
2. Donnelly DJ, Popovich PG. Inflammation and its role in neuroprotection, axonal regeneration and functional recovery after spinal cord injury. Exp Neurol 2008; 209 (2): 378-388.

3. Cizkova D, Rosocha J, Vanický I, Jergová S, Cízek M. Transplants of human mesenchymal stem cells improve functional recovery after spinal cord injury in the rat. Cell Mol Neurobiol 2006; 26: 1167@1180,

4. Zhu SP, Wang ZG, Zhao YZ, Wu J, Shi HX, Ye LB, Wu FZ, Cheng Y, Zhang HY, He S, Wei X, Fu XB, Li XK, Xu $H Z$, Xiao J. Gelatin nanostructured lipid carriers incorporating nerve growth factor inhibit endoplasmic reticulum stress-induced apoptosis and improve recovery in spinal cord injury. Mol Neurobio 2016; 53(7): 4375-4386.

5. Choi DC, Lee JY, Moon YJ, Kim SW, Oh TH, Yune TY. Acupuncture-mediated inhibition of inflammation facilitates significant functional recovery after spinal cord injury. Neurobiol Dis 2010; 39(3): 272-282.

6. Rafati DS, Geissler K, Johnson K, Unabia G, Hulsebosch C, Nesic-Taylor O, Perez-Polo JR. Nuclear factor-kappa $B$ decoy amelioration of spinal cord injury-induced inflammation and behavior outcomes. J Neurosci Res 2008; 86: 566-580.

7. Chen X, Zhou C, Guo J, Sun K, Zhao N, Yang J, Sun Y, Liu X, Hibi T, Liu Z, Han J. Effects of dihydroxylphenyl lactic acid on inflammatory responses in spinal cord injury. Brain Res 2011; 1372: 160-168.

8. Bareyre FM and Schwab ME: Inflammation, degeneration and regeneration in the injured spinal cord: Insights from DNA microarrays. Trends Neurosci 2003; 26: 555@563.

9. Barut S, Ünlü YA, Karaoğlan A, Tunçdemir M, Dağistanli $F K$, Öztürk M, Colak A. The neuroprotective effects of $z-$ REVD. fmk, a caspase-3 inhibitor, on traumatic spinal cord injury in rats. Surg Neurol 2005; 64(3):213-220

10. Byrnes KR, Stoica BA, Fricke S, Di Giovanni S, Faden AI. Cell cycle activation contributes to post-mitotic cell death and secondary damage after spinal cord injury. Brain 2007; 130(11):2977-2992.

11. Liang $W B$, Han $Q Q$, Jin $W$, Xiao ZF, Huang JC, Ni HB, Chen B, Kong J, Wu J, Dai JW. The promotion of neurological recovery in the rat spinal cord crushed injury model by collagen-binding BDNF. Biomaterials 2010; 31: 8634-8641.

12. KJ Yun, JS Shin, JH Choi, NI Back, HG Chung, KT Lee. Quaternary alkaloid, pseudocoptisine isolated from tubers of Corydalis turtschaninovii inhibits LPS induced nitric oxide, PGE (2), and pro-inflammatory cytokines production via the down-regulation of NF-KB in RAW 264.7 murine macrophage cells, Int Immunopharmacol 2009:(9);1323-1331.

13. Lixia $H$, Jun $C$, Song $H$, FaHu $Y$, Jinwen $T$. Neuroprotective effect of (-)-tetrahydropalmatine in Japanese encephalitis virus strain GP-78 infected mouse model. Microb Pathog 2018; 114: 197-203.

14. Exercise protocols using rats and mice, in Resource Book for the Design of Animal Exercise Protocols, American Physiological Society, 2006; pp 23-58. 
15. Jin W1, Wang J, Zhu T, Yuan B, Ni H, Jiang J, Wang $H$, Liang $W$. Anti-inflammatory effects of curcumin in experimental spinal cord injury in rats. Inflamm Res 2014; 63(5): 381-387.

16. Jin W, Wang HD, Yan W, Zhu L, Hu ZG, Ding YS, Tang K. Role of Nrf2 in protection against traumatic brain injury in mice. J Neurotrauma 2009; 26: 131-139.

17. Basso DM, Beattie MS, Bresnahan JC, Anderson DK, Faden Al, Gruner JA, Holford TR, Hsu CY, Noble LJ, Nockels $R$, et al: MASCIS evaluation of open field locomotor scores: Effects of experience and teamwork on reliability. Multicenter animal spinal cord injury study. J Neurotrauma 1996; 13: 3432359.

18. Jin W, Kong J, Lu TY, Wang HD, Ni HB, Wu J, Dai YX, Jiang J, Liang WB. Erythropoietin prevents secondary brain injury induced by cortical lesion in mice: possible involvement of Nrf2 signaling pathway. Ann Clin Lab Sci 2011; 41: 25-32.

19. Jin $W$, Wang $H D$, Yan $W, X u L Z$, Wang $X L$, Zhao $X N$, Yang $X H$, Chen G, Ji Y. Disruption of Nrf2 enhances upregulation of nuclear factor-kappa $B$ activity, proinflammatory cytokines, and intercellular adhesion molecule-1 in the brain after traumatic brain injury. Mediat Inflamm 2008; 725174.
20. Ormond $D R$, Peng $H$, Zeman $R$, Das $K$, Murali $R$, Jhanwar-Uniyal M. Recovery from spinal cord injury using naturally occurring anti-inflammatory compound curcumin. J Neurosurg Spine 2012; 16: 497-503.

21. Leung WC, Zheng H, Huen M, Law SL, Xue H. Anxiolyticlike action of orally administered DL-tetrahydropalmatine in elevated plus-maze, Prog. Neuropsychopharmacol Biol Psychiatry 2003; 27: 775-779.

22. Medzhitov R. Toll-like receptors and innate immunity. Nat Rev Immunol 2001;1(2):135-45.

23. Loannou S, Voulgarelis M. Toll-like receptors, tissue injury, and tumourogenesis. Mediators Inflamm 2010; 2010: 581837.

24. Chen F, Castranova V, Shi X, Dwmers LM. New insights into the role of nuclear factor-kappa $B$, a ubiquitous transcription factor in the initiation of diseases. Clin Chem 1999; 45(1): 7-17.

25. Hang CH, Shi JX, Tian J, Li JS, Wu W, Yin HX. Effect of systemic LPS injection on cortical NF-KB activity and inflammatory response following traumatic brain injury in rats. Brain Res 2004; 5: 1026(1): 23-32.

26. Liu C, Shi Z, Fan L, Zhang C, Wang K, Wang $B$. Resveratrol improves neuron protection and functional recovery in rat model of spinal cord injury. Brain Res 2011; 16; 1374: 100-109. 